\title{
THE LOSS OF BIRTHRIGHT CITIZENSHIP IN NEW ZEALAND
}

\author{
Caroline Sawyer
}

\begin{abstract}
The Citizenship Amendment Act 2005 removed the traditional common law rule that a person born in New Zealand was, just for that reason, a New Zealand citizen. It required that the person have a parent who was a New Zealand citizen or permanent resident at that time. The change is often said to have been made to prevent transient immigrants having New Zealand citizen children in order to remain in the country, after the Supreme Court's decision in the Ding and Ye line of cases reputedly confirmed that foreign parents did thus obtain that right. This article discusses the misconceptions surrounding the loss of full birthright citizenship, the background of contemporary citizenship law in the common law world and the potential effects of the recent change on migrant communities and on New Zealand's existing population.
\end{abstract}

\section{INTRODUCTION}

This article will discuss a recent change to New Zealand's citizenship laws, when the longstanding rule that a person born in New Zealand territory was automatically a citizen was changed. A child's citizenship by birth now depends on having a parent with sufficient status. It will be suggested here that the reasons usually given for making the change do not tally with the actual effects of the change. It will also suggest that the implications of the change are much broader than is generally acknowledged.

In 2005, s 5 of the Citizenship Amendment Act fundamentally amended s 6 of the Citizenship Act 1977. Section 6 of the Citizenship Act 1977 had previously provided that every child born in New Zealand (as defined for the purposes of the 1977 Act) was for that reason born a citizen of New Zealand. ${ }^{1}$ From 2006, a child born in New Zealand is automatically a citizen only if a parent is a citizen or permanent resident. The principle of birthright citizenship is variously known as the jus soli or "law of the land", distinguishing it from the jus sanguinis, or "law of blood". The pure jus soli might allow citizenship only to those born in the territory; a pure jus sanguinis system would

* Senior Lecturer, Faculty of Law, Victoria University of Wellington.

1 New Zealand for these purposes includes Tokelau, Niue and the Cook Islands: Citizenship Act 1977, s 6. 
only allow it to those whose parents were citizens, wherever they were born. ${ }^{2}$ Elements of both systems can be combined, and there are other ways of attributing citizenship, especially by naturalisation following a period of residence. Most countries operate, in law or in practice, a system that combines elements of all of these systems of citizenship attribution. New Zealand does too, and the change in 2006 may have appeared relatively minor. ${ }^{3}$ Since most people have either permanent residence rights in, or the citizenship of, the country in which they live, it is usual for most children born in a territory to be citizens even with the requirement as to parental status that New Zealand has now introduced. The numbers of children born in New Zealand without New Zealand citizenship would therefore be small. The change does however mean first that it is now possible for a person to be born in New Zealand and not to be a New Zealand citizen, even if they grow up here. ${ }^{4}$ Secondly, there has been a break with a legal cultural tradition. That break has however permeated the common law world; perhaps it is itself now part of the developing legal tradition of the common law. New Zealand's local change is in any event part of a broad political trend in its attribution of citizenship, but one which has different political meanings across the former British Empire.

The change in New Zealand away from the pure jus soli to a requirement of parental status in 2006 is often presented as having been a necessary response to the perceived problem of foreigners having babies in New Zealand in order to gain citizenship for their children. What is inferred is that the parents have intended thus to gain residence rights for themselves as parents of citizen children. It has even been suggested that the amendment was a direct response to the line of cases culminating in the Ding and Ye case, eventually decided in the Supreme Court in 2009. ${ }^{5}$ The Supreme Court held that the interests of citizen children was a relevant principle in the decision whether or not to deport their foreign overstayer parents, and could mean that the deportation would not be lawful. Popularly, that case was and is reputed to decide that such parents could not be deported. However, this is incorrect. The Ding and Ye case, and others raising similar issues, resonate with similar cases

2 Interestingly, the common use of the expression jus soli has shifted in recent years, from meaning principally where citizenship by birth in the territory is attributed to everyone, as a policy, to applying where birth in the territory is part of the qualification for citizenship, even if there is a simultaneous requirement of appropriate heritage.

3 New Zealand has long operated citizenship by descent so that the child born abroad to a New Zealand parent is a New Zealand citizen for that reason. In the common law, citizenship by descent is always of statutory origin: this strand of the legal culture began with the English statute De Natis Ultra Mare 1351 (Eng) 25 Edw 3, Stat 2, which was passed to deal with inheritance claims by those born overseas.

4 The first such people started at school in the last couple of years, and so the implications are just becoming more apparent at the public level.

5 The case will be referred to as Ding and Ye, but in the Supreme Court the title was Willie Ye, Candy Ye and Tim Ye v Minister of Immigration and Yueying Ding, and Alan Qiu and Stanley Qiu $v$ Minister of Immigration, He Qin Qiu and Ziao Yun Qui [2009] NZSC 76. 
in other common law countries. ${ }^{6}$ The responsibility for the abandonment of the pure jus soli principle is often attributed to foreigners trying to abuse it in order to outwit legitimate immigration policy. This narrative may work at the political level. However, whilst it might be possible that such outwitting is attempted serially across the common law world, and is going on when the loss of the jus soli is carried through, the idea that the latter would be a logical legal response does not work.

That is because the children's jus soli rights were not the origin of foreign parents' right to remain. Across the common law world, such parents were deported or removed, ${ }^{7}$ or they were sometimes allowed to stay for reasons which are unaffected by the abandonment of the jus soli. Legally, therefore, the loss of the jus soli is not logically about the - relatively few - unwanted foreigners who are parents of native-born citizen children, are without any form of immigration status but wish to stay, and are prepared to fight about it; their position is unchanged. This article will suggest that the loss of birthright citizenship in New Zealand was not a local issue but the local phenomenon of a global trend, and explain that the impetus for the loss of the jus soli, from the legal point of view, could not have been a matter of immigration policy and a wish to foil the ambitions of certain foreigners to obtain residence rights in New Zealand by the back door. The article will examine the details of New Zealand's legislative change as a change to the formal constitution of the citizenry of New Zealand, showing that that change amounts to a change of legal and political culture.

\section{THE CULTURES OF BIRTHRIGHT AND BLOODLINES CITIZENSHIP}

The jus soli is fundamental to the common law. ${ }^{8}$ The principles of English law were exported along with the British settlers and colonisers, themselves reproducing British power abroad. The basis of British nationality law took root in the dominions and colonies, as did other principles such as those of property law. ${ }^{9}$ The jus soli is a monarchical concept, based on the equation of a king's

6 See for example Naidike $v$ Attorney-General of Trinidad and Tobago [2005] 1 AC 538 (PC); ZH (Tanzania) $v$ SSHD [2011] UKSC 4.

7 Deportation was traditionally the expulsion of a foreigner who had committed some act making their presence positively unwanted, and removal the administrative result where someone did not have permission to enter or remain. The progressive global criminalisation of being in a country without appropriate immigration status has led to a blurring of the boundary between the two.

8 "The Citizenship Act retains the fundamental common law principle according to which citizenship is acquired by the fact of birth within the territory of the state (jus soli)." K E Dawkins "New Zealand Citizenship Redefined" (1979) 4 Otago LR 201. Modern common law citizenship policy is generally taken to have been established around the seventeenth century, after the Reformation focused the identity of the nation on the monarch throughout its fabric, and the Treaty of Westphalia formalised the modern phenomenon of the nation-state.

9 Patrick McAuslan "Property and Empire" (paper to the University of Reading Centre for Property Law Sixth Biennial Conference, 2006). 
power with his dominion over his subjects. It was first formally, and famously, affirmed by case law in the early 17 th century, in a case which confirmed that: ${ }^{10}$

Every one born within the dominions of the King of England, whether here or in his colonies or dependencies, being under the protection of - therefore, according to our common law, owes allegiance to - the King and is subject to all the duties and entitled to enjoy all the rights and liberties of an Englishman.

That concept and phrase were reflected in the first codification of British nationality in the British Nationality and Status of Aliens Act 1914, passed at the outbreak of the First World War. Section 1 of the Act confirmed that "any person born within His Majesty's dominions and allegiance" was a "natural-born British subject". ${ }^{11}$ The concept of birthright citizenship was repeated in the post-war British Nationality Act 1948, which still allowed British subjecthood (or Commonwealth citizenship) - and the right to live in the United Kingdom - to everyone born in the then Empire, but envisaged a substratum of citizenship of the newly-independent countries as the Empire broke up. Those citizenships became of primary importance, founding the relationship between the citizens of the newly-independent countries and their own governments. The British Nationality and New Zealand Citizenship Act 1948 gave New Zealand citizenship, in parallel, to everyone born in New Zealand: "every person born in New Zealand after the commencement of this Act shall be a New Zealand citizen by birth". ${ }^{2}$

The common law, including the jus soli principle, however, began to take root in New Zealand with the Treaty of Waitangi in 1840 - Māori conceptions of relationship to the territory are of a different nature. The Crown took sovereignty and recognised Māori equally as British subjects along with the British settlers. ${ }^{13}$ The jus soli principle meant that, for the purposes of the Pākehā community that was becoming dominant, the next generation of Europeans (or anyone) were as much part of the New Zealand constituency from birth as were Māori, the tangata whenua or people

10 Calvin's Case (1572) Eng R 64 (1572-1616) 7 Co Rep 1a, 77 ER 377: a boy born in Scotland in 1603, the year that James V of Scotland inherited the throne of England as well, had been improperly deprived of his lands in southern England; the defence in the case had been that he was an alien, and so not entitled to own land in England.

11 The term "British citizen" had no technical meaning until 1983; "British subject" now has an entirely different meaning from that which it had in 1914.

12 Section 4 "every person born within the United Kingdom and Colonies after the commencement of this Act shall be a citizen of the United Kingdom and Colonies by birth". This provision was subject to similar restrictions for those with diplomatic or enemy alien parents as are now in the Citizenship Act 1977 and are usual in citizenship provisions.

13 The Treaty provided that Māori had "all the rights and privileges of British subjects"; the Native Rights Act 1865 confirmed that the position of Māori was the same as that of natural-born subjects of the Crown. 
of the land. ${ }^{14}$ The jus soli principle, which deals with the citizenship of the next native-born generation, embedded a particular idea of the proper constitution of the citizenry. In the United States, the idea took a particular shape: exclusions of the native-born depended not on parental immigration status but on race: the Declaration of Independence famously declared that "all men are created equal", but slaves were plainly excluded. When an earlier decision that held that AfricanAmericans could not be citizens was overruled in 1866, Supreme Court Justice Noah Haynes Swayne in the United States saw US' birthright citizenship as rooted in English legal culture: ${ }^{15}$

All persons born in the allegiance of the king are natural-born subjects, and all persons born in the allegiance of the United States are natural-born citizens. Birth and allegiance go together. Such is the rule of the common law, and it is the common law of this country as well as of England ... since as before the Revolution

The Fourteenth Amendment to the United States Constitution followed in 1868, and still states that: "All persons born or naturalized in the United States, and subject to the jurisdiction thereof, are citizens of the United States and of the State wherein they reside." In 1898, it was confirmed that this applied to the children of unlawful migrants. ${ }^{16}$ Canada and Australia likewise retained the jus soli as part of their inheritance of the common law. ${ }^{17}$ These were all countries of substantial immigration, but immigration of a certain kind; even after they began making their own citizenship laws, some continued actively recruiting migrants from Britain, even with the explicit intention of entrenching ethnic European settlement. ${ }^{18}$ The jus soli allowed those migrant communities to become part of the formal legal fabric within a generation and to embed in turn the legal and social culture they brought with them into the new territory. In New Zealand, it embedded Pākehā.

Other countries, by contrast, have never operated principles of citizenship based on the territory of birth, but institutionalised jus sanguinis (bloodlines) systems of connection through genealogical and cultural inheritance. ${ }^{19}$ But, though the underlying culture and philosophy is entirely exclusive,

14 For a Pākehā view of tangata whenua see JGA Pocock "Tangata Whenua and Enlightenment. Anthropology" (1992) 26 New Zealand Journal of History 28; for an alternative view S Matthewman and D Hoey "Settling In: The Politics of Pākehā Ethnicity" in Public Sociologies: Lessons and Trans-Tasman Comparison: TASA/SAANZ 2007 Joint Conference Proceedings, Department of Sociology, The University of Auckland.

15 United States v Rhodes (1866) 27 Cas 785, overruling Dred Scott v Sandford (1857) 60 US 393.

16 United States $v$ Wong Kim Ark (1898) 169 US 649.

17 The jus soli is not peculiar to the common law, but is historically common to those countries, and in the Americas generally.

18 The "White Australia" policy, for example, was rooted in the mid-19th century but not finally ended until 1973. See <www.immi.gov.au>.

19 Civil law systems are historically and more generally jus sanguinis, but how far the jus sanguinis is truly a "bloodlines" rule and how far one of culture or language in any particular jurisdiction is a matter of debate. 
the practicalities may attenuate that. In practice, existing nationality and citizenship systems across the world incorporate elements of each other's structures, and have rules as to acquisition of citizenship by grant. It is, however, the marker of a jus sanguinis system that, although citizenship may be attributed to the foreign-born descendants of existing citizens, the native-born of a territory may yet not be recognised as citizens, even if they grow up in the country and never leave it. Moreover, the lack of entitlement of necessity can be inherited down through the generations, producing legally disenfranchised groups of people born and living amongst citizen neighbours. Legally, the status of a second or third-generation native-born non-citizen may be no better than that of a recent immigrant. Psychologically, such exclusion can damage the individual; at the societal level, it can damage social cohesion, especially where those who are legally citizens are erroneously identified by the vigilant as foreigners and treated accordingly. ${ }^{20}$

\section{THE DECLINE OF THE JUS SOLI}

Having been embedded across the world with the success of British imperial ambition, the jus soli has been on the decline since the sun set on the Empire, as the separate countries entrenched their identities. The first common law country to break away from the tradition of the jus soli was Britain itself. Having shed its foreign territories, it began to close the United Kingdom as well. The British Nationality Act 1981, which came into force in January 1983, established six forms of British nationality, of which only one, the new "British citizenship", carried the "right of abode" the unrestricted right to enter and remain in the United Kingdom (UK). Britain had previously restricted access to the UK from non-UK-based British nationals unless they had been born in the UK, or had a parent or grandparent who was born in the UK. This amounted to implementing a form of British jus sanguinis for non-UK-based British nationals, making the others "immigrants" in Acts of that name, though they were still British nationals. ${ }^{21}$ These rules had their origins not in nationality and citizenship legislation, but in legislation that was termed "immigration" legislation.

The change in British law began with the Commonwealth Immigrants Acts of 1962 and 1968, which restricted the entry of British nationals from East Africa. Much of that legislation was passed in a climate of corrosive race relations. The European Commission of Human Rights famously observed, in relation to a claim by an excluded group, that the exceptions to the exclusion of

Benedict Anderson famously describes communities of people who cannot all know each other personally as "imagined as both inherently limited and sovereign"; he suggested that modern nations are communities based on print-based languages. Benedict Anderson Imagined Communities: Reflections on the Origin and Spread of Nationalism (Verso, London, 1991).

20 The citizenship system of Germany was fundamentally changed in 2000, for example, by the Gesetz vom 15 Juli 1999 (BGB1 I at 1618). This followed considerable criticism of the existing strongly jus sanguinis system which had led especially to disenfranchised Turkish communities of several generations' standing, including by the United Nations in the context of the Convention on the Elimination of All Forms of Racial Discrimination.

21 Commonwealth Immigrants Acts 1962 and 1968. 
overseas-based British nationals for those with a connection with the United Kingdom by descent that would mean those allowed to enter were most likely to be white. ${ }^{22}$ This concept was originally known as "patriality"; the word excited much protest, and was dropped, but the effect remains in the Immigration Act 1971, which is still in force. ${ }^{23}$ The British Nationality Act 1981 consolidated the provision by ending the pure jus soli provision and instituting the same requirement as now exists in New Zealand under s 6 of the Citizenship Act 1977. For a person to be a British citizen by birth from 1983 onwards, at the time of that birth one parent must be a citizen or be settled in the United Kingdom.

Some former colonies and dominions abandoned the jus soli on independence, especially where past British rule was particularly resented - for example, in East Africa. The more complex case of India, with its multiple legal communities, and the countries where the European settlers were the dominant communities, retained the jus soli into the later twentieth century. India and Australia however then both followed Britain in abandoning the jus soli in the 1980s: in India, from 1986, and in Australia from 1987. ${ }^{24}$ The position in Ireland was and is more complex, because of the historical relationship between Britain and Ireland and because of the political claim of the Republic of Ireland to the whole of the territory of the island of Ireland, but birthright citizenship was part of the Irish constitution. The practice of granting residence rights to the foreign parents of citizen children had been established in case law in 1990 but was becoming controversial, and was rejected in 2003. ${ }^{25}$ In 2004, the Minister for Justice, Equality and Law Reform, Mr Michael McDowell, expressed concern about the numbers of pregnant foreign women who nevertheless continued to arrive in Ireland and often then claimed refugee status. ${ }^{26} \mathrm{~A}$ referendum was held on whether the Irish constitution should be amended to abandon birthright citizenship; ${ }^{27}$ it came just a month after the Opinion of the Advocate-General Tizzano in the Zhu and Chen case indicated the likely outcome of that case in favour of the strong rights of the Irish-born child of Chinese parents

22 East African Asians v United Kingdom (1973) [1981] 3 EHRR 76 (ECHR).

23 Current New Zealand citizens of British descent, if they have a British citizen parent, are not only a British national but also a British citizen by descent, and entitled to live and work in the United Kingdom. If they do not have a British citizen parent, but they have or had a British grandparent, they will be entitled to seek a generous form of work visa on that basis, which can lead to settlement and naturalisation.

24 In Australia, the Citizenship (Amendment) Act 1986; in India, the Citizenship (Amendment) Act 1986.

25 Fajujonu v Minister for Justice [1990] 2 IR 151, O \& L (Osayande \& Lobe) [2003] 3 ICLMD 57. In the latter case, an attempt to extend the previous rule to grandparents was also denied.

26 Siobhán Mullally has described the "moral panic" of the surrounding circumstances as involving "discrimination and exclusion arising from gender, 'race' and ethnicity and migration status" ("Migrant Women Destabilising Borders: Citizenship Debates in Ireland" in D Cooper and E Graham (eds) Intersectionality and Beyond: Law, Power and the Politics of Location (Routledge, London, 2009).

27 Referendum on the Twenty-seventh Amendment to the Irish Constitution (see SI No 170 of 2004; Referendum Act 1998). 
(discussed below) and showed a 79 per cent vote in favour of the change. ${ }^{28}$ The Irish constitution was then amended accordingly, with the loss of the pure jus soli from 2005. ${ }^{29}$

The loss of the pure jus soli has caused some difficulties in Britain, because the implementation of a jus sanguinis system depends not on the relatively simple issue of place of birth but on the status of the child's parents at the time, which may in turn depend on records that are difficult to trace. ${ }^{30}$ It is not easy, and possibly not feasible, to institute a strongly jus sanguinis system retrospectively in a country that has operated a jus soli system. The operation of such a system requires record-keeping which most countries have instituted only comparatively recently. Brubaker records that the Chirac Government in France in 1986 proposed to replace the French "double jus soli" (which attributes citizenship to the French-born children of French-born parents) with a jus sanguinis system, but found that proof of French descent entailed an "infinite regress" unless, perhaps, an ancestor had a certificate of naturalisation (those established in France from birth would necessarily lack documentation showing that); eventually it gave up the endeavour. ${ }^{31}$ Whilst the jus soli requires for its efficient functioning only a reliable system of birth registration, the jus sanguinis can call for enquiries in archives beyond the dreams even of many academics. Moving from a pure jus soli system to a jus sanguinis system can thus be an administrative, as well as a philosophical, issue. Official records will need to show the status in New Zealand of the parents of anyone born here after 2005, at the time of their birth. However, New Zealand's way of recording status, the formality involved in reaching New Zealand's shores (it is almost impossible to arrive without being tracked via the visa system) and the unlikelihood of anyone plausibly asserting an unrecorded physical presence from an extra generation back may make that relatively workable.

28 Chen $v$ Secretary of State for the Home Department [2004] CMLR 48.

29 Not only the rights of migrants' children but the dignity and poetry of the constitution's language suffered: "It is the entitlement and birthright of every person born in the island of Ireland, which includes its islands and seas, to be part of the Irish Nation" became:

Notwithstanding any other provision of this Constitution, a person born in the island of Ireland, which includes its islands and seas, who does not have, at the time of the birth of that person, at least one parent who is an Irish citizen or entitled to be an Irish citizen is not entitled to Irish citizenship or nationality, unless provided for by law.

30 This issue did not seem to permeate practice for some years. For example, a child born in Britain in 1993 and initially granted a British passport without question might find only in his teens that he could not renew it without showing that his mother, part of the Caribbean diaspora who came to the UK in the 1970s, had formal settled status at the time of his birth.

31 Rogers Brubaker Citizenship and Nationhood in France and Germany (Harvard University Press, Cambridge, 1992) at 151-152. The proposals also entailed more detailed difficulties, for example in relation to the second generation of Algerian immigrants; Algeria had been part of France (not a colony), but there was an attempt to exclude its population from French nationality after decolonisation. 


\section{THE LOSS OF BIRTHRIGHT CITIZENSHIP IN NEW ZEALAND}

The Citizenship Act 1977 as originally drafted preserved the pure jus soli in New Zealand, but after the Citizenship Amendment Act 2005, only those born in New Zealand to a parent who was a New Zealand citizen or permanent resident obtained New Zealand citizenship by virtue of that birth. There is a pervasive perception, including amongst lawyers, that the reason for the abandonment of the jus soli in New Zealand was the line of cases that culminated in the decision of the Supreme Court in Ding and $\mathrm{Ye}^{32}$ In that case, the Chinese overstayer parents of New Zealand-born citizen children were to be deported to China. That presented two unpalatable options for the children: to accompany their parents out of their own country of New Zealand, thus losing the opportunities New Zealand offers to its children, or to stay in New Zealand without their parents. Immigration officers took the view that family unity trumped other considerations, so the parents should leave and the children should go with them. The Supreme Court, however, held that New Zealand's obligations under the United Nations Convention on the Rights of the Child (UNCRC) required a broader approach to children's welfare, with a potentially different outcome. ${ }^{33}$

The meaning of the judgment was that, in truly exceptional cases such as lack of medical services or education or civil war in parents' home countries, the "constructive deportation" of children along with their parents might be inappropriate, and the proper course could be to allow the parents to remain. ${ }^{34}$ The popular understanding appears to have been, however, that the Supreme Court said that the parents of New Zealand citizen children should not or possibly even could not be deported. That fundamental idea is of course also central to the myth that the loss of birthright citizenship in the Citizenship Amendment Act 2005 was a result of its encouraging foreigners otherwise liable to deportation to "hide for as long as you can and have as many children as you can". 35

32 Ye and Qiu v Minister of Immigration [2009] NZSC 76. An earlier case on a similar issue, Tavita $v$ Minister of Immigration [1994] 2 NZLR 257 (CA) also gave rise to much commentary: see for example Claudia Geiringer "Tavita and All That: Confronting the Confusion Surrounding Unincorporated Treaties and Administrative Law" (2004) 21 NZULR 66 at 66-105.

33 Convention on the Rights of the Child 1577 UNTS 3 (opened for signature 20 November 1989, entered into force 2 September 1990) This requires at art 3 that

In all actions concerning children, whether undertaken by public or private social welfare institutions, courts of law, administrative authorities or legislative bodies, the best interests of the child shall be a primary consideration.

New Zealand ratified the UNCRC in 1993.

34 Nuala Mole "Constructive Deportation and the European Convention" (1995) EHRLR 63.

35 Ye v Minister of Immigration [2008] NZCA 291, [2009] 2 NZLR 596 at [573] per Chambers J. A leading New Zealand practitioner, David Ryken, took to the pages of the New Zealand Herald to discourage people from making such applications, or from paying "certain immigration advisers" to help them do so (David 
The misperception that the Supreme Court judgment meant that the foreign parents of child citizens could stay in New Zealand for that reason appeared in turn to arise from two errors, the first being a misunderstanding about the status of children's interests under the Supreme Court judgment. The UNCRC requires that children's interests be a "primary" consideration, allowing them to be weighed against considerations such as immigration policy. Though the popular version has it that the Supreme Court judgment made the children's citizenship, or their interests, "paramount", the reality is different. The attempt to imply the "paramountcy" provisions of the Care of Children Act 2004, was given short shrift by the court: "The Care of Children Act is not concerned with immigration matters in respect of which the Immigration Act states the relevant policies." ${ }^{36}$ The court no doubt read the section correctly, as referring to private law decisions about day-to-day care. The UNCRC prohibits discrimination in relation to national origin, but it does not make children's interests paramount in citizenship and immigration decisions. ${ }^{37}$ If children's interests were to be paramount in public, immigration issues, let alone citizenship, New Zealand would be obliged to admit and provide fully for all the world's children and their families.

The second error is the existing effect on the parents' position of their children's New Zealand citizenship. In truth, neither citizenship nor immigration law ever required New Zealand to admit (or allow to stay) the foreign parents of citizen children just because of the children's citizenship. Citizens or permanent residents may sponsor their parent to seek residence in New Zealand, but the requirements for sponsorship have always meant that the families involved in these disputed cases have fallen outside those rules, which predate the jus soli and remain in force in largely the same shape. ${ }^{38}$ Given the breadth of New Zealand's immigration policy in relation to workers, there would be few families in which minor children were in a position to sponsor parents who could not obtain immigration status much more easily by reason of their own skills and earning capacity. The ability to sponsor the admission of parents for residence is not an absolute right incident to citizenship. If there is a choice between living in New Zealand without one's parents or leaving New Zealand to be

Ryken "Consultants may be giving false hope to overstayers" The New Zealand Herald (online ed, Auckland, 11 September 2009). As he pointed out, the issue was whether, when the foreign parent of a New Zealand citizen child was being removed, there should be consideration of the child's situation on a "humanitarian" basis. Section 47 of the Immigration Act 1987, then in force, provided that if such considerations made a removal "unduly harsh or unjust", then the removal should not take place. The Supreme Court held that that test should apply throughout the removal process, not just immediately prior to removal, and that the issue was not discretionary, but the test remained a high hurdle to satisfy.

Ye v Minister of Immigration [2009] NZSC 76, [2010] 1 NZLR 104.

37 Convention on the Rights of the Child, art 2.

38 It is for an immigration officer to deem whether or not a person is acceptable as a sponsor. The relevant rules under F4 of the Immigration New Zealand's Residence rules (see Operational Manual which requires the child sponsor (who will almost certainly be an adult child), amongst other things, to have been resident in New Zealand for three years before the application and to guarantee accommodation and maintenance for the parents for five years. Wealthy parents may still come as a special type of investors. 
with them, resolving that is regarded as a choice for the family members, not the responsibility of Immigration New Zealand or the New Zealand polity. In this, New Zealand law follows the generality of common law countries, just as New Zealand practice is following a widespread practice of tightening up on border, especially with respect to those who might be more likely to be a financial burden on the state than an economic asset.

The loss of the pure jus soli is thus unrelated at the legal level to the Ding and Ye lines of cases. The legal problem perceived was minimal or non-existent, since foreign parents of citizen children were unlikely to obtain admission or resist removal, for example on the expiry of a work visa, on the basis of their children's citizenship status. As a cure for the [non-existent] problem, since it has to do with international law limits on the permissible disruption to children's practical situation and not their citizenship status, equally the abandonment of the jus soli does not work, since the provisions enunciated by the Supreme Court in Ye apply to children regardless of citizenship. The Citizenship (Amendment) Act 2005 was not logically about preventing the foreign parents of child citizens from obtaining residence rights in New Zealand.

\section{THE SUBJECTION OF CITIZENSHIP IN THE COMMON LAW}

An alternative approach to this line of cases has however been suggested. In her discussion of the Ding and $Y e$ cases, Claudia Geiringer deprecated the Court of Appeal's abandonment, Glazebrook $\mathrm{J}$ aside, of Baragwanath $\mathrm{J}$ 's idea of a common law respect for the rights of citizenship. ${ }^{39}$ If there were such a respect, it might lend weight to the idea that allowing citizenship to the nativeborn children of foreign parents would make it more likely that the parents would have to be allowed to stay in New Zealand. That would mean there was more practical point to the loss of the jus soli. It seems however that although it may be assumed that the incidents of citizenship include a strong and practical right to live in one's own country, so strong that it can outweigh other considerations such as immigration control, that rarely applies in practice.

It is unsurprisingly fundamental to the idea of citizenship that citizens should be free to enter and remain in their own country. It is however not the sort of issue that a Citizenship Act deals with; that is concerned with who is a citizen. Entering and remaining is a matter of immigration status; citizens are exempt from the Immigration Act requirements to obtain a visa to enter New Zealand. ${ }^{40}$ International and regional law sometimes prohibits the expulsion of citizens, ${ }^{41}$ but nothing guarantees that a country must make a citizen's residence easy or even reasonably practicable. Glazebrook $\mathbf{J}$ in the Court of Appeal pursued the idea of being able to live in one's own country as a

39 Claudia Geiringer "Ding v Minister of Immigration; Ye v Minister of Immigration" NZCPL Working Paper, VUW-NZCPL-001 (paper presented to the Legal Research Foundation conference, Auckland, 12 September 2008).

40 Immigration Act 2009, s 13.

41 Perhaps surprisingly, Protocol No 4 to the ECHR, which does this, is optional. The UK has not signed it. 
fundamental incident of citizenship, but as a matter more of principle than law. ${ }^{42}$ In reviewing the case-law, she directly rejected the argument that the child citizen's residence is purely a matter for the parents' choice: ${ }^{43}$

This "choice" is not a free choice but one required of the parents because of the State's actions in removing the parent. The "choice" is either to deprive the children of the benefits of their citizenship by removing them from New Zealand or to deprive them of the benefits of growing up with a parent. ... [If the parents did leave the child alone in New Zealand], however, the removal order must be seen as the real and operative cause of the disintegration of the family unit. Equally, if the parents take the child out of New Zealand, this can be seen as a de facto removal of the child by the State.

In support of her view, she also cited Harrison $\mathrm{J}$ in Al-Hosan v Deportation Review Tribunal, ${ }^{44}$ where such arguments were described as "artificial and disingenuous", and the similar view of the Privy Council in Naidike $v$ AG of Trinidad and Tobago. ${ }^{45}$ What is said in those cases does not however amount to anything that will really fulfil what Glazebrook J earlier called "the cardinal and absolute residence right of citizens". ${ }^{46}$ In Schier, she says, the High Court "did take a more sensitive stance on citizen children faced with possible de facto removal". Neverthless, that stance amounted to holding: ${ }^{47}$

... that the degree of likelihood that other family members, especially New Zealand citizens, would in practical terms have to leave New Zealand was a relevant consideration in any appeal against a removal order.

The nature of that "especially" is very elusive. The fundamental right of citizens to live in the territory of their own country is far from clear. In the context of the citizen children of foreign parents, the United Kingdom Supreme Court addressed it directly in ZH (Tanzania), asking: ${ }^{48}$

$\ldots$ in what circumstances is it permissible to remove or deport a non-citizen parent where the effect will be that a child who is a citizen of the United Kingdom will also have to leave?

42 Ye v Minister of Immigration, above n 35, at [97-109].

43 Elika v Minister of Immigration [1996] 1 NZLR 741 at 749 (HC); Schier v Removal Review Authority [1998] NZAR 230 (HC) at 239; P v Director-General of CYPS [1998] NZFLR 977 (HC) at 989; this citation is from Ye v Minister of Immigration [2008] NZCA 291 at [103-104].

44 Al-Hosan v Deportation Review Tribunal HC Auckland CIV 2006-404-003923, 3 May 2007 at [65]

45 At [105]

46 At [99].

47 At [106].

$48 Z H$ (Tanzania) v SSHD [2011] UKSC 4 at [1]. This judgment was foreshadowed by the judgments of Lord Brown of Eaton-under-Heywood and Baroness Hale of Richmond in Naidike $v$ Attorney-General of Trinidad and Tobago [2005] 1 AC 538 (PC). 
The persistence of the issue in Britain, which lost the pure jus soli in 1983 and consequently has no minor children born under it, is a further confirmation that the ending of the jus soli does not mean an end to the legal questions around citizen children with foreign parents: the father of the children in this case, aged 12 and nine, was in "fragile health", suffering with HIV and "reported to drink a great deal". ${ }^{49} \mathrm{He}$ was however a British citizen, so the children were too. The mother, on the other hand, was a Tanzanian national with an "appalling" immigration history, whom the Home Office wished to remove. ${ }^{50}$ Allowing the appeal on its facts and largely on the basis of a correct interpretation of the primacy of the children's best interests, the court concluded nevertheless that: ${ }^{51}$

... if a child is a British citizen, this has an independent value, freestanding of the debate in relation to

best interests, and this must weigh in the balance in any decision that may affect where a child will live.

This case, however, was the culmination of considerable pressure on the issue, and it changes the existing law very little. The children's citizenship must be adverted to, but there is nothing to prevent its being found insufficient to prevent removal of the parents. ${ }^{52}$

The loss of the jus soli in Britain, and its relationship with Ireland, led to a European case which revealed, however, a very different approach to the meaning of citizenship rights in that legal context. Citizens of the member states of the European Union, which includes both Britain and Ireland, are citizens of the European Union. "European citizenship" is not however a sep arate territorial citizenship but consists principally of the rights that the European Union requires member states to extend to each other's citizens. ${ }^{53}$ European Union law has developed strong rights for thirdcountry nationals who are family members of European citizens. These are obligatory for all European member states, but those states remain free to choose their own citizenship system, and

49 At [3].

50 At [5].

51 At [47].

52 In the New Zealand Court of Appeal case of Ding, above n 37, indeed, Glazebrook J cited the pressure immigration officials put on Mrs Ding to leave and take the citizen children to China with her; there is nothing in these cases that will necessarily displace that approach at [107].

53 This leads to the phenomenon known as "reverse discrimination", where a European Union citizen has greater rights (such as the right to bring in a spouse) in other European Union countries than in their home country, where they cannot exercise European Union rights but only domestic ones. Attempts to avoid this by dual nationals have so far failed, as the case of McCarthy $v$ Secretary of State for the Home Department C-434/09 showed. This concerned a British woman who wished to bring into Britain her Jamaican husband. It is well established that the partner of a British citizen does not get a right to enter Britain as such from that relationship. However, the free-movement rights of a European Union citizen who is the national of another country include bringing in a partner. McCarthy was a British national who had always lived in Britain, but was entitled to Irish nationality, which she obtained in order to bring in her third-countrynational partner to Britain. The matter was referred to Luxembourg for a preliminary ruling, and it was held that the right to bring in her partner was a free-movement right and could be exercised only in that situation. 
Europe shows a wide range of those. ${ }^{54}$ In Zhu and Chen $v$ SSHD, a Chinese mother gave birth to a daughter in Belfast in $2002 .{ }^{55}$ Belfast is in Northern Ireland, and so in the United Kingdom, but Catherine Zhu was not entitled to British citizenship by birth because neither of her parents had sufficient status; Mrs Chen was present on a temporary visa. However, at that time the Republic of Ireland still operated the jus soli across the whole of the island of Ireland. Catherine was therefore entitled to Irish citizenship, and when the pair were later apprehended in Cardiff (in Wales, another part of the UK), Mrs Chen claimed to benefit from Catherine's rights under European Union law to live wherever she liked in Europe provided she had sufficient financial resources. ${ }^{56}$ Moreover, she claimed that, to make the right meaningful, little Catherine had to have her mother with her, and the European Court of Justice (ECJ) in Luxembourg agreed with her. British immigration law was amended to take account of the judgment; the abandonment of the jus soli in Ireland would mean that the issue would recede over time. But the Luxembourg court has established in European Union law a strong form of citizenship, within which the incidental rights are to be taken seriously. Since the Zhu and Chen case, the matter has gone further: in the ECJ case of Zambrano, the court held that the Columbian father of dependent children who were Belgian citizens therefore had a right of residence in Belgium, and did not require permission to work there. ${ }^{57}$ But it remains the case that no overarching rules apply to the attribution of citizenship itself.

The Luxembourg court is however out on a limb. If one looks elsewhere for judicial support for the idea that the right of abode is a "cardinal and absolute" incident of citizenship, one does not find it. The other supranational European jurisdiction, the European Court of Human Rights (ECtHR) at Strasbourg, enforces the Council of Europe's European Convention on Human Rights (ECHR); those rights may also be taken into domestic law. The ECHR is very strong in that it is enforceable by the individual who suffers a breach, but the rights it defends are relatively limited, negative, individual rights. They do not include positive rights against the state, and they do not cover matters of admission and expulsion, but they do include (unlike the New Zealand Bill of Rights Act) a right to respect for private and family life which can found resistance to the deportation of residents'

54 The European Convention on Nationality CETS 166 (opened for signature 6 November 1997, entered into force 1 March 2000), which contains neither obligation nor prohibition of the pure jus soli but principally encourages naturalisation procedures for long-term lawful residents, has a patchy record of signature and ratification.

55 Chen v Secretary of State for the Home Department Case C-200/02 [2004] CMLR 48.

56 Art 18 EC. Directive 90/364 [1990] OJL 00/00, Art 1 (1).

57 Ruiz Zambrano (European citizenship) [2011] EUECJ C-34/09, 8 March 2011. In the contemporaneous case of Derici, which also addressed the advantageous position of Turkish citizens as third-country nationals, it was also held that the family members of citizens, as opposed to those exercising rights of free movement, could be excluded, but only provided this did not prevent the citizen from genuine enjoyment of their rights as citizens of the Union: Murat Dereci and Others $v$ Bundesministerium für Inneres CJEU C-256/11, 15 November 2001, at [33-34]. 
family members. ${ }^{58}$ That right was asserted in the cases of Jaramillo and Sorabjee, which concerned citizen children born after the loss of the jus soli to parents of mixed nationalities. When they were left in the care of the non-British parent who became subject to deportation, the foreign parents sought to resist on the basis of the children's to be brought up by a parent and in their own country. The expectation was that the ECtHR, having previously deprecated the assertion of rights incident on pure jus soli citizenship, which it considered "theoretical", would recognise the incidents of a jus sanguinis citizenship. This inference of the fundamental correctness of a jus sanguinis system is itself an interesting piece of judicial intervention: notably, in $Z H$ (Tanzania), Barones Hale of Richmond also remarked: ${ }^{59}$

They are British children; they are British, not just through the "accident" of being born here, but by descent from a British parent; they have an unqualified right of abode here.

Yet jus soli citizenship was a codified rule by the time of the First World War and so, one might think, hardly "accidental". ${ }^{60}$ But in Jaramillo and Sorabjee, the expectation that the new, restricted citizenship rule would found a fundamental right of abode, that the law had realistically to fulfil in the way as in the ECJ case of Zhu and Chen, was however confounded. The ECtHR refused to entertain the claims and ruled them inadmissible. ${ }^{61}$

A search for a common law respect for a realistic right of abode as an incident of citizenship, as advocated by Glazebrook $\mathrm{J}$ or implemented in an alternative system by the ECJ in the Zhu and Chen case should be informed by the fate of the Chagos Islanders in the British courts. The treatment of former inhabitants of the British Indian Ocean Territories and their descendants by the British government was asserted, even in court action in the late 20th century, to be a breach of Magna Carta. The islanders were taken off the island, the largest of which, Diego Garcia, was then leased to

58 Abdulaziz Cabales and Balkandaliv United Kingdom (1985) 7 EHRR 471 (ECHR). Article 8 contains the right to respect for private and family life, subject to such restrictions as may be reasonably necessary in a democratic society. Article 8 can be widely used to realise rights, but whether it requires a country to allow the person or family admission or immigration status depends on the conditions abroad. Article 8 would have been in issue in the Ding and $Y e$ cases had it occurred in a country signatory to the ECHR.

$59 Z H$ (Tanzania) v SSHD [2011] UKSC 4, at [31].

60 British Nationality and Status of Aliens Act 1914, s 1.

$61 O$ and $O L \vee U K$ (1989) 11 EHRR 46 (ECHR). The cases of Jaramillo $v$ United Kingdom (24865/94), Sorabjee v United Kingdom (2398/94) and Ajayi v United Kingdom (27663/95) were ruled inadmissible: European Commission of Human Rights, Strasbourg 23 October 1995; for discussion see Nuala Mole, op cit note 34 above. When citizenship with a jus sanguinis element was discussed in ZH (Tanzania) [2011] UKSC 4, however, that element was apparently given some considerable weight at [31]. (see note 48 above). 
the United States as an air base. ${ }^{62}$ The islanders appealed amongst other things to the guarantee that: 63

No freeman shall be taken or imprisoned, or be disseised of his freehold, or liberties, or free customs, or be outlawed, or exiled, or any other wise destroyed; nor will we pass upon him, nor condemn him, but by lawful judgment of his peers, or by the law of the land.

They eventually pursued action through the English courts for compensation for the loss of their islands and they made claims for British citizenship. ${ }^{64}$ In the course of this, they obtained the right in principle to return to the islands, but it never materialised, and in October 2008, in the last domestic case, the House of Lords held against them. It did not infer, for example, that art 8 of the ECHR, perhaps taken with art 3 as in the East African Asians case (see above, note 22), required the Court to infer a right to live in one's own country, and nor did it find that citizenship was a constitutional right particularly capable of withstanding the will of Parliament. It held that "the right of abode is a creature of the law. The law gives it and the law may take it away." The idea that the right of abode holds a special place in the incidents of citizenship was addressed directly, to be dismissed: 65

In this context I do not think that it assists the argument to call it a constitutional right. ... I quite accept that the right of abode, the right not to be expelled from one's country or even one's home, is an important right. ... But there seems to me no basis for saying that the right of abode is in its nature so fundamental that the legislative powers of the Crown simply cannot touch it.

62 The use of Diego Garcia for "extraordinary rendition" was the subject of investigation by the Parliamentary All-Party Group on Extraordinary Rendition. The US lease expires in 2016; a proposal to establish a marine park in the area is currently before Permanent Court of Arbitration at the Hague.

63 Magna Carta 1215, art 39.

64 Bancoult, $R$ (on the application of) v Secretary Of State For Foreign \& Commonwealth Office [2000] EWHC 413 (Admin); $R$ (On The Application of Bancoult) $v$ Secretary of State for Foreign and Commonwealth Affairs [2008] UKHL 61; [2007] EWCA Civ 498; [2006] EWHC 1038 (Admin); Chagos Islanders v Attoney-General Her Majesty's British Indian Ocean Commissioner [2003] EWHC 2222 (QB); [2004] EWCA Civ 997.

65 At [45]. The islanders had also lodged an application in 2004 to the European Court of Human Rights claim based on art 3 (inhuman and degrading treatment) in respect of various aspects of their removal from the islands and reception conditions in Mauritius and the Seychelles and the prohibition on return to the islands; art 8 (respect for their private life and their home); art 1 of Protocol No 1 (deprivation of their possessions and use of them); art 6 (right to a fair trial) in respect of the administrative and court treatment of their claims; art 13 (right to an effective remedy). In December 2012 it was held inadmissible on the grounds that the islanders' claims had come to an end when they accepted an arrangement for the payment of compensation in 1982. 
This is not to say that New Zealand might not have a different take. Sir Robin Cooke pointed out that New Zealand's common law departed "to a significant extent" from that of England, ${ }^{66}$ and he believed that "some common law rights presumably lie so deep that even Parliament could not override them." ${ }^{67}$ But the reference there was to the right not to be tortured, and one can only speculate as to whether the right of abode would have been included. Certainly no succour for its fundamental nature can be found in the English common law.

During the currency of the Chagos Islanders' case, Britain took a further and more dramatic step in relation to citizenship rights, offending so much against the general idea of what is constitutional that many British people decline to believe what the legislation says and to believe that the nativeborn cannot be deprivied of their citizenship. Although the deprivation provisions had been changed to include the native-born in 2002, to some public disquiet, changes in 2006 then allowed deprivation of citizenship (and those non-citizens with the right of abode to be deprived of that right) if the Secretary of State considered such deprivation to be "conducive to the public good". 68 This is achieved not by process but by delivery of a notice (perhaps by post), and is virtually irresistible (save on the grounds of ensuing statelessness). It is so close to arbitrary deprivation as to make little practical difference. There was little general appreciation especially that the section applies equally to those born in Britain, though a burst of publicity in the media in early 2013 may have changed that. ${ }^{69}$ The ease with which this law passed, however, did not suggest the overriding of any acknowledged fundamental common law right.

It remains to be seen whether this further fundamental constitutional change to the legal relationship between the native-born and the territorial government spreads across the common law world as the loss of the jus soli has done. The loss of the jus soli precedes the 'War on Terror', which is the justification for the more extreme version of denial of citizenship to the native-born. In the United States, it is perhaps in any case less necessary, as deviant citizens may be disposed of by extra-judicial execution, which in the United Kingdom would be a breach of the right to life under

66 The Rt Hon Lord Cooke of Thorndon "Final Appeal Courts: Some Comparisons Occasional Paper No 7" (New Zealand Centre for Public Law, Victoria University of Wellington, December 2001).

67 Taylor v New Zealand Poultry Board [1984] 1 NZLR 394 (CA) at 398.

68 Nationality, Immigration and Asylum Act 2002, s 4; Immigration and Asylum Act 2006, ss 56 and 57; amending British Nationality Act 1981, s 40. For discussion see Caroline Sawyer "'Civis britannicus sum' no longer: deprivation of British nationality" (2013) JIANL 23. In relation to those with the right of abode, it is noted that under the "draft (partial) Immigration and Citizenship Bill" published for consultation in July 2008, a widespread deprivation was proposed. The Bill had widespread publicity as liable to resolve all Britain's immigration problems, but it was never clear how it would work in practice and it was subsequently withdrawn by not being mentioned in the next Queen's Speech.

69 Chris Woods, Alice K Ross and Oliver Wright "British terror suspects quietly stripped of citizenship... then killed by drones" The Independent (online ed, London, 28 February 2013). 
the ECHR. ${ }^{70}$ Since the United States has hard constitutional provisions in relation to citizenship which are so far resistant to the withdrawal of the jus soli itself, it might be that this further step is unthinkable. Moreover, the 'War on Terror' seems to be overtaken as a focus of international concern by the global financial crisis and the incipient collapse of the international banking system. However, in the United States, citizenship is governed by the Constitution, so changes are particularly difficult to achieve and may be the reason for a perception that suspected terrorists have to be pursued by other means. Whilst New Zealand often follows international trends in immigration and citizenship provisions, ${ }^{71}$ this particular aspect of the trend to exclusion may be resistible here.

\section{CONCLUSION}

It is a fundamental feature of the State sovereignty on which international law is based that states can define their own members; they are very unwilling to let that framework go - as witness, for example, the relatively few signatories to the Convention on the Reduction of Statelessness. ${ }^{72}$ Within it, the attribution of citizenship is a matter of individual legal culture. The reasons for the differences between the character, or idiom, of the jus soli system and that of the jus sanguinis was considered by Brubaker in his famous comparison between the French and German citizenship systems ${ }^{73} \mathrm{He}$ rejected an instrumentalist explanation for the difference in favour of an explanation based on political culture, finding that France's adoption of the "double jus soli" system, under which a person born in France to a parent also born in France is recognised as a citizen, was related to the fact that non-citizens did not do military service rather than caused by it, as was sometimes alleged. France did not need more soldiers, but the exclusion of the second generation born in France was found to be anomalous because they were considered to be French "in fact if not in law". ${ }^{74}$ Frenchness was thus popularly a matter of where the individual lived rather than a matter of heritage. Brubaker contrasts France's "state-centered and assimilationist" approach, where "the specifically political and statist quality of French nationalism has permitted, even required, a citizenship law that would transform immigrants into Frenchmen" with "the German understanding of nationhood as an essentially ethnocultural fact, prior to and independent of the state". ${ }^{75} \mathrm{He}$

70 ECHR, art 2 (right to life). As with the current practice of deprivation of British citizenship, the cognate US policy is executed outside the country: when the Central Intelligence Agency was authorised to target Anwar al-Awlaki for killing, that had to be authorised by the National Security Council because he was a US citizen; he and his son Abdulrahman were killed by drones in September and October 2011 respectively.

71 See for example the Mass Immigration Act 2013.

72 Nottebohm (Liechtenstein v Guatemala) [1955] ICJ 4. However, states do widely attribute citizenship to the stateless born on their territory, though it can be very difficult to prove that one is stateless.

73 Brubaker, above n 31.

74 At 14 . The issue of military service has historically been a big issue in international consideration especially of dual citizenship; where it applies, it greatly affects both the individual (who may not wish to serve) and the state (which may want soldiers, but cannot conscript foreigners).

75 At $14,51-52$. 
comments that these "distinctive and deeply-rooted ... understandings of nationhood have remained surprisingly robust." ${ }^{76}$ The New Zealand approach is the opposite, but perhaps represents a similar idea: the native-born children of immigrants were (at least according to the popular versions of the Ding and $Y e$ cases) considered, in fact, and are now considered in law, to be foreigners.

In New Zealand's modern legal system, the jus sanguinis has been grafted onto the well-rooted idiom of the jus soli, giving rise to a cultural change. If the general legal culture is regarded as the one inherited from New Zealand's past place in the now-defunct British Empire, then the move is definitely a break with that past. As discussed above, however, the change is broadly in line with a general change in the common law countries; in effect the closing of boundaries after the age of Empire and a more general closing of borders in an age of anxieties. New Zealand's unique geographical situation - it is almost impossible to arrive physically without a visa or visa waiver means however that it is also differently placed from most jurisdictions in relation to policing its borders, since that takes place almost entirely through the processes of visa issuing and enforcement. $^{77}$

Those could not, however, have caused the loss of the jus soli, at least not for legal reasons. Whilst in New Zealand, as in Ireland, there was an apparent moral panic about the rights of citizen children to act as "anchor babies" for their foreign-national parents, the decision as to change was made pursuant not to referendum, fuelled by the popular view (whether as to the effect of the jus soli on foreign parents, or merely on their native-born children), but through the parliamentary process. ${ }^{78}$ Within that more considered process, it will obviously have been observed that neither the jus soli nor the children's nationality was the focal issue in Ding and Ye. The rights that line of cases gave to the children, which in exceptional cases meant that their foreign-national parents could remain in New Zealand, stem from the UNCRC, which prohibits discrimination on the grounds of national origin. If citizenship does not of itself give any rights, the implication of that would be that its withdrawal would be of no effect. Indeed, in Ding and Ye itself, Tipping J addressed the issue in order to distance the court from it: ${ }^{79}$

76 At 3. It should be noted that Brubaker was publishing in 1992, in relation to the system established under the Staatsangehöringkeitgesetz of 1913, before the radical adjustment to German citizenship law brought about by art 2 des Gesetzes vom 15 Juli 1999 (BGBl I at 1618).

77 Carriers' liability - which makes ships' captains or airlines or other carriers responsible for taking back those who are denied entry, thus effectively outsourcing much of the work of checking them - was instituted in New Zealand in the nineteenth century; see now Immigration Act 2009, Part 4.

78 This is the term used in the US for the citizen children of foreign parents who thereby seek the right to remain in the US; it can be a pejorative term.

79 Ye v Minister of Immigration (SC), above $\mathrm{n}$ 36, at [12]. This is mirrored in ZH (Tanzania) [2011] 4 UKSC at [32], where the "intrinsic importance" of the British citizenship of children was discussed as a factor in whether or not their Tanzanian mother, who had an "appalling" immigration history, should be deported. 
The views expressed in these reasons are not necessarily applicable to cases involving children born in New Zealand after 1 January 2006. Whether and to what extent the earlier position is any guide to that obtaining after the change in the law, will require careful consideration in a case where the children have no right, as citizens, to remain in New Zealand.

The legal context of the change in New Zealand is however also different and stricter from that in the other countries that have also abandoned the jus soli. Citizenship attribution under s 8 of the Citizenship Act 1977 as it currently stands is in some ways broad, but in other, more fundamental, ways it is very restrictive. ${ }^{80}$ The people excluded from New Zealand citizenship after the loss of the jus soli are the children of transient tourists and overstayers, but also the children of those still on work visas at the time of the child's birth who subsequently remain, obtain residence visas and naturalise. The equivalent Australian legislation allows Australian citizenship not only to those born in Australia to an Australian citizen or resident parent but also to the Australian-born who reside in Australia for their first ten years. New Zealand has no such provision; nor does it have a provision equivalent to the British "long residence rules", which give a right to remain to lawful or unlawful residents after specified lengthy periods, or the rules as to registration for children born in Britain without status who nevertheless live there until the age of ten. ${ }^{81}$ Moreover, there is no right to family life in New Zealand equivalent to that of art 8 of the ECHR. ${ }^{82}$ The use of Ministerial discretions might compensate for the hard line of New Zealand legislative policy, but the current harder line of compliance (enforcement) may however itself present difficulties. In particular, the practice of not recording the reasons for decisions under s 61 of the Immigration Act 2009 sought to prevent any revisiting at all of any decision taken, in practice, by an immigration officer, until, after pressure from the profession, it was ended in September $2013 .{ }^{83}$

Debate remains in the UK, where there is less reliance on the impact of the UNCRC as such, as to how important that citizenship was to the court's decision.

80 New Zealand includes Niue, Tokelau and the Cook Islands (Citizenship Act 1977, s 3); - the primary legislation allows Tokelauan mothers who give birth in Samoa just for the medical attention available there to be treated as giving birth in Tokelau, and New Zealand citizenship is not lost by adoption by non-New Zealand parents.

81 In the UK, the "Long Residence Rule": para 276B(i)(a) of the Immigration Rules gave settlement after ten years' lawful residence, now subject to a suitability test, and 14 years' unlawful residence, the latter being replaced in July 2012 with a 20 -year provision based on the establishment of a private life in the UK. Section 1(4) of the British Nationality Act 1981 entitles children born in the UK who are not born citizens but continue to live in the UK for ten years to register as citizens provided they have not spent more than 90 days outside the United Kingdom in any of those years.

82 M v Refugee Status Appeals Authority [2012] NZCA 83; M v Minister of Immigration [2013] NZSC 9; [2013] 2 NZLR 1.

83 Workforce (Immigration New Zealand) "Internal Administration Circular 11/10" (14 November 2010) SDE-32; Immigration New Zealand Instructions: Amendment Circular 2013/13 (30 September 2013). 
New Zealand's constitutional position is, as in Britain but in contrast to the US and notwithstanding the suggestions of Lord Cooke, generally changeable at the whim of Parliament. ${ }^{84}$ It is however in a different political position. It has no substantive internal terrorist threat and no particular fear of violent attack. It does however have longstanding policies which Thomas Janoski has suggested have resulted in an ethnic anomaly: ${ }^{85}$

New Zealand is perhaps the most ethnically British of all countries (perhaps even more than the United

Kingdom, which has had considerable immigration) and immigration and nationality policies are the reason why.

It is suggested here that restrictive immigration and citizenship policies do not preserve a common law culture. The implicit categorisation of Janoski of Britain as less "British" because of immigration is contestable (if not illogical); immigration is historically fundamental to the constituency of Britain and the process of national ethnic change that represents. Legal acceptance of that change was embodied in the jus soli, until that itself changed in the later 20th century. ${ }^{86}$

Restraining unlawful immigrant families from becoming part of the legal social fabric of necessity entrench the existing ethnic mix, as indeed does any nationality system to some extent. In the context of its geographical isolation and lack of immigration and citizenship rights accruing to family relationships or after periods of de facto residence, New Zealand's loss of birthright citizenship will be particularly effective. In the current global economic climate, it is likely to remain an attractive destination for the skilled workers it desires to attract, and so long as permanent resident status continues to be generously attributed, the effects of this change to citizenship law on migrant workers' families is unlikely to deter them. The new provisions are not uncommon on the global scene. It remains to be seen, however, how the change works out in the context of New Zealand's unique bicultural framework. The jus soli embedded Pākehā in a country with an established conception of territorial belonging. Pākehā were and are not tangata whenua. The Pākehā legal system has included the commodification of land and a relatively free market in it, restricted only by the approval requirements in relation to foreign investors, save insofar as Māori have established their claims. ${ }^{87}$ There may be some irony perceived in ending the legal tradition that allowed Pākehā to find an equal legal place for and with Māori community in the past, since the effect would now be to maintain the fabric of a European constitutional culture in the South Pacific

84 Perhaps with the exception of Electoral Act 1993, s 268; see above n 66.

85 Thomas Janoski The Ironies of Citizenship: Naturalisation and Integration in Industrialised Countries (Cambridge University Press, Cambridge, 2010) at 114. He notes that although after the establishment of New Zealand citizenship, the right to naturalisation was restored to Chinese immigrants, but the right to immigrate was itself very restricted.

86 See Robert Winder Bloody Foreigners (Little Brown, London, 2005).

87 Te Ture Whenua Māori Act 1993; Te Ture Whenua Māori (Amendment) Act 2002. 
against a perceived threat of exactly the sort of uninvited, but non-hostile, immigration that established that constitutional culture in the first place. 